\title{
Implementation Of The Settlement Of The Case Restorative Justice In Fights By Children Because The Effect Of Liquor (Case Study In The Polres Kudus)
}

\author{
Hadi Noor Cahyo ${ }^{1}$ and Maryanto ${ }^{2}$
}

Abstract. Settling disputes fight by children because of the influence of liquor based on the Law applicable Relative authority possessed by police, then in handling $A B H$, the police can make or use the authority the discretion of the need to continue the legal process.

Restorative Justice approach used in settling disputes fight by children because of the influence of liquor in the best interest of children of law enforcement officers are already implementing Discretion (Police Authority) and Diversion Restorative Justice approach based on each brat who committed the crime. According to Act No. 11 Of 2012 on Child Criminal Justice System, Restorative Justice approach is highly required as for the approach made through Diversion is applied at every stage of the proceedings. With the Discretion (Police Authority) and Diversion at every stage of the proceedings under the Child Criminal Justice System provides a great opportunity to keep the child out of the judicial process that is not needed in order to maintain mental, moral, and future of the child.

Obstacles and solutions for settling disputes fight by children because of the influence of liquor through the mechanism of Restorative Justice Approaches Related to the competence of the investigators in the field of legal knowledge, laws and regulations, the criminal justice system and the technical skills and tactical investigation is still not optimal. This happens because not all personnel functions reskrim follow vocational education and skills of detectives technical functions supporting for example the ability to use information technology in the disclosure of a criminal case. Including in this case the lack of a comprehensive understanding of the principles of restorative justice.

Keywords: Restorative Justice, Kids Fighting, Liquor.

\section{Introduction}

One of the effects of modernization of the new socio-economic factors is quite real in our communities is the abuse of liquor in teenagers. If this condition is allowed then the disaster will happen, teenagers who have alcohol poisoning or alcohol are not effective for adolescent social life. ${ }^{3}$

Crime is a complex phenomenon that can not be understood from many different sides. That is why in our daily lives can capture a variety of comments about an event that is different from one another. In this experience was not easy to understand the crime. $^{4}$

\footnotetext{
${ }^{1}$ Students Master of Law, Unissula, Email: h44dinc@gmail.com

${ }^{2}$ Faculty of Law Unissula

${ }^{3}$ Basman, SH, Gangguan Orang Mabuk dan upaya Penanggulangannya, Gramedia Pustaka Utama, Jakarta. 2004, p. 82

${ }^{4}$ Topo Santoso, Eva Achjani Zulfa, Kriminologi, PT Raja Grafindo Persada, Jakarta, 2001, p. 3.
} 
Problem drinking and drunks on most people generally do not revolve around whether authorized or prohibited liquor used. The issue basically is who gets to use it, where, when, and what conditions. Consequently layman argues that liquor is a stimulant. While the stimulant itself is to enhance the activity that stimulates the central nervous system and increases one's physical ability, but in fact the liquor is a protoplasmic poison that has a depressant effect on the nervous system. As a result, a drunk less and less ability to control themselves, whether physical, psychological or social, but it should be noted that reliance on liquor is a separate process, the wear of time. ${ }^{5}$

After discussing the prohibition of fights set Qur'an further seen positive legal rules governing such matters. Which is contained in the Criminal Code (the Code of Criminal Law) Article 358 "Those who deliberately participate in the attack or fight in which involved several people in addition to the responsibility of each to what is typically carried out by it," With a maximum imprisonment of two years eight months, if as a result of the attack or fight was no serious injuries. With a maximum imprisonment of four years, if consequently there are dead ". 6

But all the rules that are above both the rule of Allah and of man himself still rife fights conducted by the community of Undaan Kudus District.

Based on the problems described above, the authors are interested in doing research in the form of legal writing and discuss it in the form of a thesis with the title "Implementation of The Settlement Of The Case Restorative Justice In Fights By Children Because The Effect Of Liquor (Case Study In The Polres Kudus)"

\section{Research Methods}

The method used is qualitative analysis, namely data obtained through fieldwork and research literature then arranged systematically, and then analyzed qualitatively to achieve clarity issues to be discussed. The data is then analyzed using a theoretical and interpretive positive law which has been poured and then deductively conclude to address existing problems. ${ }^{7}$

\section{Results and Discussion}

\subsection{Settling Disputes Fight By Children Because Of The Influence Of Alcohol Pursuant Based on Law}

In general the criminal justice process, a person who has committed a criminal act against him will be investigated by the police when there is a complaint or caught redhanded committing a crime. Based on the results of the investigation, if a person is found guilty the arrest and further investigation is a series of actions the investigator in the case and in the manner set forth in this law to search for and collect evidence with evidence that shed light on criminal acts that occurred and to find the suspects.

\footnotetext{
${ }^{5}$ Soerjono Soekanto, Sosiologi Suatu Pengantar ,Jakarta: PT. Raja Gratindo Persada, 1990, p. 418

${ }^{6}$ R. Soenarto Soerodibroto. KUHP dan KUHAP. Jakarta: PT. RajaGrafindo Persada, 1994, p. 219-220.

${ }^{7}$ Ibid, p.119
} 
Based on interviews Investigators Undaan police chief AKP Mr. Anwar. SH. ${ }^{8}$ A series of acts of investigation carried out in order to serve the dossier to be submitted to the prosecutor's office as a public prosecutor in the trial, but the criminal justice process for children in conflict with the law should be distinguished by the criminal justice process commonly given the psychological condition of the child is not adequate and need protection from the government.

Some interesting facts in prisons is generally applicable in all the countries which are the most filling prisons are poor and weak, the prison led to the increase in the crime rate for the state is the place to learn all kinds of crime, imprisonment causes detainees be brutal, prison can ruin a relationship either between the perpetrator with his family as well as society, prison is where rampant drug and other drugs, the deterrent effect is a myth because despite the threat of punishment criminal offense continues to increase, the crime rate stays up and eventually prison also led to high costs due to high operation of life and prison building maintenance are expensive.

Most of the regulations pertaining to the handling of minors has been basically seek to apply restorative justice even if its application has not been comprehensively. Act No. 3 of 1997 on Juvenile Court also contain elements of restorative justice that is different from normal judicial procedure as it was before the trial opened, the judge will be Commander in order to deliver social counselors kemasyakatan research reports regarding the child. Based Interview police chief of Undaan Mr Anwar. SH. ${ }^{9}$ said that the judges will get a more comprehensive explanation of the proceedings that promote the best interests of the child (for the best interest of the child)

Based on interviews Investigators from Undaan Mr. Suheni. ${ }^{10}$ In practice the elements of restorative justice that does not work well because some constraints are interlinked with each other to complicate efforts to protect children's rights. Juvenile justice in Indonesia is still violating the rights of children are reflected in the court actions which are still found the existence of the death penalty against child cases, have not met the right of children to be accompanied by lawyers, parents and officials from the Institute of Corrections, as well as the persistence of deprivation of children unauthorized for civilian children were placed together with the state child and criminal children are children who are placed in a correctional institution for legal recognition has committed a crime.

Settling disputes fight by children because of the influence of liquor under the Act and regulations. Handling children in conflict with the law do not have to use the means nonpenal (eg, diversion) or use the criminal law (penal), but both can be done sequentially, ie prioritizing diversion (if they meet the requirements of diversion), and if such efforts fail it will enforced the criminal justice system for children. In general, the application of the criminal justice system for the settlement of the criminal case may be harmful to children, particularly the provision of "the stigma of evil" in children (stigmatization or labeling), and the occurrence of bad habits in correctional institutions (prisons) are then practiced again by children outside the prisons, even the

\footnotetext{
${ }^{8}$ Interview with Undaan police chief AKP Mr. Anwar, SH On December 4, 2018

${ }^{9}$ Ibid.

10 Interview with Investigators from Undaan Mr. Suheni On December 4, 2018
} 
repetition of offenses more serious consequences. One reason is the direct contact with law enforcement to make the child frustrated. ${ }^{11}$

Experts in the field of psychology, law, etymology criminal, criminology, education, and Penology always find the best solution for the child, the victim and the public interest, and plan restorative justice approach as an alternative idea to reduce the weaknesses of the theory of punishment retributive theory of prevention as well as the theory of joint, Restorative justice is a movement of ideas and perspectives that promote justice the perpetrators and their families, victims and their families, communities, and stakeholders in order to restore the state of each.

\subsection{Restorative Justice Approach Used In Settling Disputes Fight By Children Because Of The Influence Of Liquor}

Juvenile justice system in Indonesia is obliged to prioritize the best interests of the child and the child is trying to reduce the settlement in criminal court, and if forced sentenced to imprisonment, the criminal is only done as a last resort and in a short time.

According Wardaya and Retnaningrum, as quoted byWidodo, ${ }^{12}$ said that public awareness that children need to be treated criminals as adults specifically not only realized since the implementation of juvenile justice first time in Chicago in 1889. The urgency of implementation of diversion in case the child is based on the following reasoning. At present there is a shift of philosophy of punishment from the beginning that is restitutif (retaliation) is then matched into the theory of prevention (goal), then came the merger theory, and eventually developing restorative justice thinking that prioritizes the recovery. Restorative approach represents a new paradigm in the different sentencing approach retributive justice, good concept, orientation, objectives and mechanisms to achieve them. Retributive justice was born as a reaction to some of the weaknesses of retributive justice approach.

A change of paradigm of justice in criminal law is a worldwide phenomenon because the public is increasingly aware that there needs to be a radical change concerning the settlement fights done by children because of the influence of liquor. Juvenile justice system that is based on retributive justice and restitutif give full authority to the law enforcement agencies without giving the opportunity for settling disputes fight by children because of the influence of liquor, and the recipient to deliver justice version they want.

Determined degree of justice for victims by providing jail terms for offenders. This has become one of the factors increasing level of crime committed by the settlement fights done by children because of the influence of liquor because they actually can learn jailed crime that has never been done before on other prison inmates.

Figures retributive theory is Immanuel Kant and Hegel. Their views are absolutely going to trust a criminal conviction, even if the criminal is actually useless. The view is directed to the past and not the future and can be redeemed at fault has to suffer. The fundamental characteristics of a retributive theory or the theory of this absolute.

\footnotetext{
${ }^{11}$ Ibid.

${ }^{12}$ http: //id.portalgaruda. org. accessed on December 5, 2018
} 
including the purpose of punishment is only for retaliation, retaliation only the main goal and not a means to achieve other objectives, such as public welfare (social welfare). Moreover, the moral wrong (moral guilt) is a condition of the sole purpose of sentences meaning of sentences should be in accordance with the moral fault of criminal offenders and look back on as a reproach and the goal is not to improve, educate or meresosialisasi perpetrators.

Cessare Beccaria (1738-1794) did harsh criticism towards the objective of sentencing in retributive theory above. Beccaria questioned whether criminal prosecution is a suitable means to a crime. Do sentencing someone really useful and important to maintain security and public order of the threat of crime and whether torture against perpetrators will achieve justice as promoted by law. Based on the above, according to Beccaria purpose of punishment is to prevent someone to commit a crime and not a means of revenge society (the purpose of punishment is to Deter person from the commission of the crime and not to provide social revenge). Therefore a cruel punishment do not benefit the security and public order. Crime prevention efforts by Beccaria better to do preventive measures than do criminal prosecution.

On the other hand Jim Consedine as one of the pioneers of restorative justice argue that the concept of retributive justice and restitutif which is based on punishment, revenge against the perpetrators, exile and destruction should be replaced by restorative justice, which is based reconciliation, the restoration of victims, integration into society, forgiveness.

Furthermore mem- provide an explanation related to differences in case management paradigm fights done by children because of the influence of liquor as follows:

Investigators Undaan from the interview Mr. Heru Purwoko. ${ }^{13}$ With respect authority possessed by police, then in case handling fights done by children because of the influence of liquor, the police can make or use the authority the discretion of the need to continue the legal process. In this case known as the discretion of the police, the police authority to stop operation by releasing the suspect case investigation or transferred (diversion), and the goal that children avoid further legal proceedings.

\subsection{Obstacles And Solutions For Settling Disputes Fight By Children Because Of The Influence Of Liquor Through The Mechanism Of Restorative Justice Approaches}

These barriers arise from the surrounding community because people often assume that the police is an institution that is institutionally tasked to maintain security and order and protect the people. However, sometimes people choose to settle the case amicably for a variety of reasons, they do not want the family was arrested and so on. Whereas cases of fights due to alcohol is not sepeleh that can only be to the settlement without the authorities, because these actions are extremely dangerous and disturbing the public. Even the prevalent effect also did not materialize for the offender. ${ }^{14}$

\footnotetext{
${ }^{13}$ Interview with investigators from Undaan Mr. Heru Purwoko. Date December 6, 2018

${ }^{14}$ Interview Mr. Anwar, op.cit.
} 
Their limitations Human Resources (of the Police) to Address Issues Such rapid progress in various fields, especially the occurrence of acts of fights due to alcohol were in the district Undaan, the police claimed to be more professional in the investigation and the investigation is increasingly difficult to be detected, prevented and resolved both in the short time since the general power Undaan police investigator on the majority has no experience or extensive knowledge before being appointed as the investigator in dealing with such offenses in order to suppress the occurrence of fights due to alcohol. Police personnel Undaan still less than the number of population and land area. Police personnel Undaan still some who lack discipline and do not complete the tasks assigned to them. ${ }^{15}$

If the view of the data Undaan police personnel could be said personnel is very limited because it only consists of 39 while the area $71.77 \mathrm{~km} 2$. With a large population to population66,000soul to the jurisdiction of the subdistrict Undaan n. Because police Undaan perbatasaan with Pati regency, Demak and Grobogan that the majority of human resources is still low. Coupled with people who have hot blood that the slightest friction would be a conflict. Whether it's a fight, persecution, murder and so on. ${ }^{16}$

The rapid progress in various fields, especially the occurrence of acts of fights due to alcohol in the district Undaan, the police claimed to be more professional in the investigation and the investigation is increasingly difficult to detect, prevent and done well in a short time due to the generally force investigators at police Undaan partially big has no experience or extensive knowledge before being appointed as the investigator in tackling such crime. This limitation of infrastructure facilities including the lack of official vehicles owned by a police patrol Undaan to hold events regularly in each jurisdiction are considered vulnerable and need supervision at all times.

The solution to be able to suppress the occurrence of settling disputes fight by children because of the influence of liquor needed alleviation efforts. Based on interviews with the police chief AKP Undaan Mr. Anwar, SH. ${ }^{17}$

\section{Closing}

\subsection{Conclution}

- Implementation of diversion in the juvenile justice system as mandated by the Act of Juvenile Justice Openness is the best solution for the alternative Minors because the application prefers the principle of best interest of the child in terms of both physical and psychological. In this case the Case Resolution Fighting is done by the child because of the influence of liquor brought in the judicial process is a serious case and the judgment is only a last resort by taking into account and does not ignore the rights of the child. Implementation of diversion also must be implemented at all levels of good examination of investigation, prosecution up to examination in the court, but the process of implementing this diversion of the role

\footnotetext{
${ }^{15}$ Ibid.

${ }^{16}$ Ibid.

${ }^{17}$ Ibid.
} 
of the family, the school where most of the time children spent in school as well as the social environment. This is because the development of the child after the completion of legal proceedings involving children were also affected by the reception of the surrounding environment.

- Minors case brought in the judicial process is serious cases, and even then must always give priority to the principle of the best interests of the child, as well as the condemnation process is a last resort while not ignoring the rights of the child. Beyond that cases of children can be solved through non-formal mechanism based on firm standards. Non-formal forms of treatment can be done with a diversion or restorative justice that can be solved by requiring children in conflict with the law to participate in education or training in a particular institution, or if it had to happen punishment of children's rights should not be ignored. So in the end the handling of non-formal can be done well if matched by efforts to create a conducive legal system.

- These barriers arise from the surrounding community because people often assume that the police is an institution that is institutionally tasked to maintain security and order and protect the people. However, sometimes people choose to settle the case amicably for a variety of reasons, they do not want the family was arrested and so on. Whereas cases of fights due to alcohol is not sepeleh that can only be to the settlement without the authorities, because these actions are extremely dangerous and disturbing the public. Even the prevalent effect also did not materialize for the perpetrators solusinyaPihak police in the effort to cope with such acts, has been doing some prevention. For example, through a religious approach called Visits to the mosque to mosque. The police work closely with religious leaders who are in the working area

\subsection{Suggestion}

- In order to maximize the application of restorative justice diversion as the embodiment of the opinion of the author takes the strong commitment of the law enforcement agencies in dealing with minors. This can be done by forming a team specialized in handling minors at every level of the examination, which the team must be given education and training in an optimal and sustainable certification on the application of diversion. Education and training is not only given to the judge handling the case but the child is also given to the investigators and the prosecution since the diversion process must be done at every level. It also disaran that you make counseling teacher at the school receive special training related to handling children in conflict with the law.

- Need to do public education for the public to equate an understanding that is comprehensive and complete about various laws related to restorative justice as a reflection of the national identity, which is characterized restorative justice, characterized by Indonesia. Structurally need for socialization of traditional justice and restorative justice with a combination of mechanisms of criminal justice with customary justice as public participation, within a mediation meetings to get an agreement between the victim, the perpetrator, the victim's family, the perpetrator's family, as well as the relevant parties to the case. 
- Eliminating institutional egos in the police force that can inhibit process improvement abstarksi values dianur by social institutions. Strengthening cooperation with social institutions by way of socializing and discussing cases that are being handled.

\section{Bibliography}

[1] Basman, 2004, Gangguan Orang Mabuk dan upaya Penanggulangannya, Gramedia Pustaka Utama, Jakarta.

[2] R. Soenarto Soerodibroto, 1994, KUHP dan KUHAP, Jakarta: PT. RajaGrafindo Persada.

[3] Soerjono Soekanto, 1990, Sosiologi Suatu Pengantar, Jakarta: PT. Raja Gratindo Persada

[4] Topo Santoso, Eva Achjani Zulfa, 2001, Kriminologi, PT Raja Grafindo Persada, Jakarta.

[5] http: //id.portalgaruda. org. accessed on December 5, 2018

[6] Interview with investigators from Undaan Mr. Heru Purwoko. Date December 6, 2018

[7] Interview with Investigators from Undaan Mr. Suheni On December 4, 2018

[8] Interview with Undaan police chief AKP Mr. Anwar, SH On December 4, 2018 